\title{
Penerapan Diferensial untuk Mengukur Laju Perubahan Volume Air Galon
}

\author{
Muhammad Minan Chusni ${ }^{\star}$, Khoirun Nisa, Muhammad Haidir, dan Rismaya Fitriyani \\ UIN Sunan Gunung Djati Bandung \\ Jl. A.H.Nasution No. 105 Bandung, Jawa Barat Indonesia 40614 \\ *E-mail: minan.chusni@uinsgd.ac.id
}

\begin{abstract}
Abstrak
Penelitian ini bertujuan menerapkan hukum Torricelli untuk mendapatkan nilai kecepatan cairan yang mengalir, dengan cara menghitung laju perubahan volume air galon dengan menggunakan persamaan turunan dan mengukur lama waktu yang dibutuhkan sampai air di dalam galon tersebut habis. Penelitian ini menggunakan metode eksperimen dengan memvariasikan ketinggian cairan dalam galon sehingga diperoleh variasi nilai kecepatan cairan dan laju perubahan volume. Hasil penelitian menunjukkan bahwa kecepatan cairan yang maksimum yaitu $0,22 \mathrm{~m} / \mathrm{s}$ dengan laju perubahan volume sebesar $0,010 \mathrm{~m}^{3} / \mathrm{s}$, dan kecepatan cairan minimumnya yaitu $0,063 \mathrm{~m} / \mathrm{s}$ dengan laju perubahan volume sebesar $0,0028 \mathrm{~m}^{3} / \mathrm{s}$.
\end{abstract}

Kata kunci: Hukum Torricelli, Kecepatan cairan, Laju perubahan volume.

\section{Abstract}

The aim of this research is to apply Torricelli law in order to determine flow velocity of fluid by calculating the rate of change of gallon bottled water volume by using the derived equation and measuring the time required until the water in the gallon is exhausted. This research used experimental method by varying the height of liquid in gallons so that the variation of fluid velocity and the rate of volume change are obtained. The results show that the maximum fluid velocity was $0.22 \mathrm{~m} / \mathrm{s}$ with a rate of change of volume of $0,010 \mathrm{~m} / \mathrm{s}$, and the minimum fluid velocity of $0.063 \mathrm{~m} / \mathrm{s}$ with a rate of change in volume of $0,0028 \mathrm{~m}^{3} / \mathrm{s}$.

Keywords: Torricelli law, fluid velocity, rate of volume change.

\section{PENDAHULUAN}

Matematika sebagai cabang keilmuan yang mengalami perkembangan secara terusmenerus mempunyai peranan penting dalam penyelesaian suatu permasalahan (Miranti, Hidayat, \& Kusbudiono, 2014). Banyak fenomena yang ditemukan model matematika, namun model matematikanya mengandung laju perubahan, sehingga diperlukan persamaan diferensial sebagai perhitungan matematis untuk memecahkan masalah-masalah tersebut (Widyaningrum, Waluya, \& Wuryanto, 2012). Dari fenomena yang ada dapat dianalisis dengan menggunakan berbagai macam sudut pandang, salah satunya adalah dengan menggunakan kemampuan penalaran (Syafari \& Sinaga, 2017). Kemampuan penalaran merupakan komponen yang penting dari pendidikan karena diperlukan untuk memahami matematika khususnya, dan mengembangkan ide-ide agar dapat menganalisis situasi baru yang dihadapi dalam semua aspek (Ramdhani, 2017). Misalnya percepatan yang merupakan laju perubahan kecepatan terhadap laju perubahan waktu dan kecepatan yang merupakan laju perubahan jarak terhadap laju perubahan waktu (Arwan, Azizah, \& Irwan, 2014).

Persamaan diferensial merupakan persamaan yang berkaitan dengan turunan suatu fungsi atau memuat suku-suku dari fungsi tersebut dan turunannya (Alwi, Abidin, \& Ratnasari, 2015). Pengertian lain dari persamaan diferensial adalah persamaan matematika untuk fungsi satu variabel atau lebih, yang menghubungkan nilai fungsi itu sendiri dan turunannya dalam berbagai orde 
(Nuraeni, 2017). Operator diferensial umumnya ditulis $D$ (Yulida, 2012). Pada tahun 1986, Zhou memperkenalkan suatu metode yang dapat diterapkan dalam penyelesaian persamaan diferensial tak linear tanpa linearisasi terlebih dahulu yang disebut Metode Transformasi Diferensial (MTD) (Side, Hirdi, \& Ja'farudin, 2015).

Metode yang digunakan untuk solusi persamaan diferensial adalah metode analitik, tetapi ada persamaan yang tidak dapat diselesaikan dengan menggunakan metode analitik sehingga diperlukan adanya metode lain untuk mendekati nilai sebenarnya yaitu dengan menggunakan metode numerik (Muhammad, Apriliani, \& Hanafi, 2015). Secara umum ada dua macam persamaan diferensial, yaitu persamaan diferensial biasa dan persamaan diferensial parsial (Alfionita \& Zulakmal, 2012). Sedangkan nama lain persamaan diferensial parsial nonliniear yang hiperbolik adalah persamaan Saint Venant (Pratiwi, Widjajanti, \& Wyrasti, 2013). Persamaan diferensial parsial adalah persamaan-persamaan yang mengandung satu atau lebih turunan-turunan parsial (Khamidiyah \& Pagalay, 2014). Biasanya persamaan nonlinier sangat sulit untuk dipecahkan secara efektif baik secara numerik maupun analitik (Fathonah, Zulkarnaen, \& Sukaesih, 2017). Turunan fungsi di satu titik dapat dijelaskan sebagai nilai limit dari laju perubahan rata-rata ketika mendekati satu titik tertentu. Penyelesaian persamaan linear-non linear adalah mencari titik potong fungsi secara eksplisit dengan sumbu $x$, demikian juga penyelesaian persamaan diferensial adalah mencari fungsi yang memenuhi persamaan (Salusu, 2012). Selain itu, turunan fungsi di satu titik juga dapat dijelaskan sebagai nilai gradien garis pada fungsi ketika mendekati titik tertentu (Mardiana, Susiswo, \& Hidayanto, 2016). Jika suatu variabel $y$ bergantung pada waktu $t$, maka turunannya $\frac{d y}{d t}$ disebut perubahan laju sesaat. Tentu saja, jika $y$ mengukur jarak, maka laju sesaat ini disebut kecepatan (Purcell, Varberg, \& Rigdon, 2007).

Penerapan perubahan laju sesaat dalam Fisika pada materi fluida dinamis yang di dalamnya terkandung hukum Torricelli. Wujud dari eksperimen yang untuk membuktikan hukum Torricelli ialah sebuah wadah yang berisi air dan pada dindingnya terdapat sebuah lubang kebocoran. Hukum Torricelli merumuskan apabila volume air pada wadah tersebut dianggap tidak terbatas karena seallu terisi, maka debit air yang keluar dari lubang kebocoran tidak membuat volume air pada wadah berkurang. Kecepatan air yang keluar dari lubang kebocoran selalu tetap, dan posisi vertikal (tepat berada di bawah permukaan) jatuhnya air juga akan tetap (Benenson, 2000).

Hukum Torricelli dapat diterapkan pada suatu galon yang diisi oleh air, pada bagian bawah terdapat keran untuk keluarnya air, laju perubahan volume air dibandingkan dengan ukuran tangki. Sebelum keran galon dibuka dan air keluar dari galon pada ketinggian tertentu, air memiliki energi potensial, dan saat air keluar dari keran, energi potensial berubah menjadi energi kinetik. Energi potensial pada ketinggian air adalah $m g h$, dengan $g$ adalah percepatan gravitasi bumi, $m$ adalah massa dan $h$ adalah ketinggian. Misalkan kecepatan air yang keluar dari keran pada saat ketinggian air $h$ adalah $v(h)$, maka energi kinetik yang dihasilkan adalah $\frac{1}{2} m v(h)^{2}$

(Groetsch, 2012)

Berdasarkan hukum kekekalan energi, energi potensial yang dihasilkan air dalam keadaan diam diubah menjadi energi kinetik, sehingga diperoleh kesamaan (gesekan antara air dengan galon diabaikan)

$m g h=\frac{1}{2} m v^{2}$

Dengan menyederhanakan persamaan 2 diperoleh rumus untuk kecepatan $v$ yaitu,

$v=\sqrt{2 g h}$

Jadi kecepatan air yang keluar dari keran dipengaruhi oleh ketinggian air (Tipler, 1998). Sebuah galon diisi dengan air sampai ketinggian tertentu. Kemudian membuka keran galon tersebut. Menurut Hukum Torricelli 
Semakin lama, kecepatan air keluar semakin kecil sesuai dengan ketinggian cairan yang semakin menurun (Halliday, Resnick, \& Walker, 2005). Rumus diatas ditemukan oleh Evangelista Torricelli (1608-1647) dan dikenal sebagai hukum Torricelli (Suciati \& Sidarto, 2009).

Tujuan dari penelitian ini adalah menerapkan hukum Torricelli, untuk menghitung laju perubahan volume air galon dan menghitung berapa lama waktu yang dibutuhkan sampai air di dalam galon tersebut habis. Laju perubahan volume dalam sebuah tabung dihitung dengan menggunakan aplikasi turunan (Djohan \& Budhi, 2007). Laju perubahan volume didapatkan dari aplikasi turunan. Penelitian ini menggunakan alat penampung air berupa tabung sehingga volumenya air pada tabung dapat dirumuskan dengan persamaan 4 .

$$
V=\pi r^{2} h
$$

dan laju perubahan volumenya sebagaiman dirumuskan pada persamaan 5 .

$$
\frac{d V}{d t}=\pi r^{2} \frac{d h}{d t}
$$

(Purcell, Varberg, \& Rigdon, 2007).

\section{METODE/EKSPERIMEN}

Penelitian ini menggunakan metode eksperimen dengan memvariasikan ketinggian air dalam galon sehingga diperoleh variasi kecepatan air dan laju perubahan volume air. Alat dan bahan yang digunakan dalam penelitian ini yaitu:

A. Alat dan Bahan
1. Galon ukuran 10 liter 1 buah
2. Penggaris 1 buah
3. Stopwatch 1 buah
4. Air 1,5 liter

\section{B. Prosedur Penelitian}

Prosedur penelitian yang dilakukan pada penelitian ini sebagai berikut:

1. Menyiapkan alat dan bahan penelitian.

2. Meletakkan galon ditempat yang tinggi.
3. Memasukkan air secukupnya dalam galon dengan keran galon yang masih tertutup.

4. Menggunakan stopwatch untuk menghitung waktu keluarnya air dari galon.

5. Membuka keran pada galon untuk mulai penelitian dan menekan stopwatch secara bersamaan.

6. Mengamati sampai air di dalam galon habis.

7. Mematikan stopwatch secara bersamaan ketika air di dalam galon habis.

8. Mengulangi langkah 3-8 untuk variasi tinggi air yang berbeda.

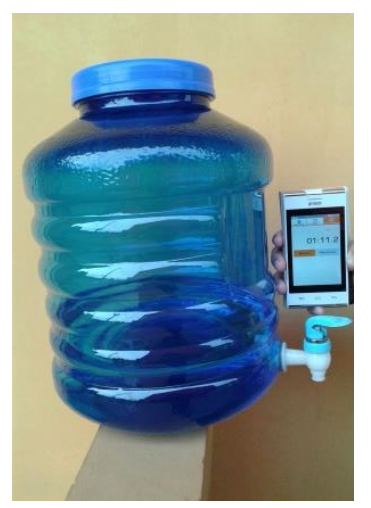

Gambar 1. Rangkaian alat penelitian

\section{HASIL DAN PEMBAHASAN}

Penelitian ini untuk menganalisis laju perubahan volume air dalam sebuah tabung dengan menggunakan turunan dan hukum Torricelli. Penelitian dilakukan sebanyak lima kali untuk mendapatkan variasi data ketinggian mula-mula $h_{2}$ dan dan ketinggian air pada saat pengosongan galon (air sudah tidak lagi mengalir lewat keran) $h_{2}$ sebagaimana diperlihatkan pada Gambar 3.

Dari hasil penelitian perubahan volume air pada galon diperoleh data sebagamana disajikan padaTabel 1 . 
Tabel 1. Data waktu pengosongan galon dengan variasi ketinggian cairan. $\left(\frac{d V}{d t}\right)$ yang berupa garis linear. Dengan

\begin{tabular}{cccc}
\hline No & $\boldsymbol{h}_{\mathbf{1}}(\mathrm{m})$ & $\boldsymbol{h}_{2}(\mathrm{~m})$ & $\boldsymbol{t}(\mathbf{s})$ \\
\hline $\mathbf{1}$ & $5 \times 10^{-2}$ & $31 \times 10^{-2}$ & 625 \\
$\mathbf{2}$ & $5 \times 10^{-2}$ & $25 \times 10^{-2}$ & 436 \\
$\mathbf{3}$ & $5 \times 10^{-2}$ & $19 \times 10^{-2}$ & 296 \\
$\mathbf{4}$ & $5 \times 10^{-2}$ & $13 \times 10^{-2}$ & 262 \\
$\mathbf{5}$ & $5 \times 10^{-2}$ & $7 \times 10^{-2}$ & 122 \\
\hline
\end{tabular}

Pengolahan data dari Tabel 1 peneliti mencari kecepatan air menggunakan persamaan (3), dan laju perubahan volume menggunakan persamaan (5), sehingga diperoleh data seperti pada Tabel 2.

Tabel 2. Hasil Laju perubahan volume galon dan kecepatan air

\begin{tabular}{ccc}
\hline No & $\frac{d V}{d t}\left(\mathrm{~m}^{3} / s\right)$ & $(v \pm \Delta v) m / s$ \\
\hline $\mathbf{1}$ & 0,010 & $0,2280 \pm 0,0003$ \\
$\mathbf{2}$ & 0,0090 & $0,2000 \pm 0,0004$ \\
$\mathbf{3}$ & 0,0075 & $0,1670 \pm 0,0004$ \\
$\mathbf{4}$ & 0,0056 & $0,1260 \pm 0,0006$ \\
$\mathbf{5}$ & 0,0028 & $0,0630 \pm 0,001$ \\
\hline
\end{tabular}

Dari Tabel 2 bisa dibuat grafik hubungan kecepatan aliran air dengan laju perubahan volume seperti pada Gambar 1.

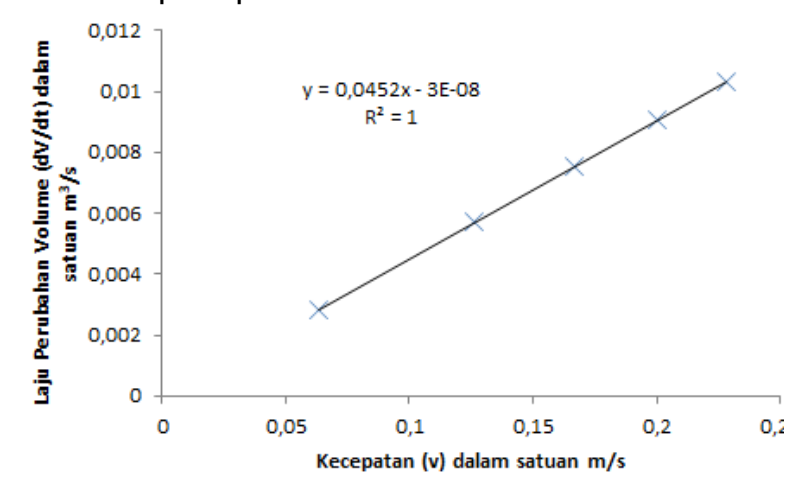

Gambar 1. Grafik Hubungan antara Kecepatan dan Laju Perubahan Volume

Pada Gambar 1, dapat dilihat bahwa dari kalibrasi didapatkan grafik hubungan antara kecepatan $(v)$ dan laju perubahan volume graden grafik sebesar 0,0045 nilai gradien grafik tersebut adalah nilai $\pi r^{2}$ sebagaimana adalah $m=\frac{y}{x}$ dimana sumbu $y$ adalah $\frac{d V}{d t}$ dan sumbu $x$ adalah $\frac{d h}{d t}$ dari persamaan (5) dapat dijabarkan seperti persamaan 6 .

$$
\pi r^{2}=\frac{\frac{d V}{d t}}{\frac{d h}{d t}}
$$

persamaan (6) menunjukan nilai gradien. Grafik tersebut sesuai dengan persamaan (5) yang menunjukan laju penurunan air berbanding lurus dengan laju perubahan volume air. Berdasarkan hitungan manual untuk $\pi r^{2}$ hasilnya yaitu $0,045 \mathrm{~m}^{2}$ hasil ini didapatkan dengan mencari selisih laju perubahan volume yang terbesar dan terkecil, dan selisih kecepatan yang terbesar dan terkecil. Kemudian membagi selisih laju perubahan volume dengan kecepatan sebagaimana hasil pada Tabel 2, nilai ini sama dengan nilai gradien yang didapat dari grafik.

Penelitian ini untuk menentukan laju perubahan volume pada tabung, untuk mencari kecepatan aliran airnya menggunakan hukum Torricelli dan untuk mencari laju perubahan volumenya menggunakan aplikasi turunan.

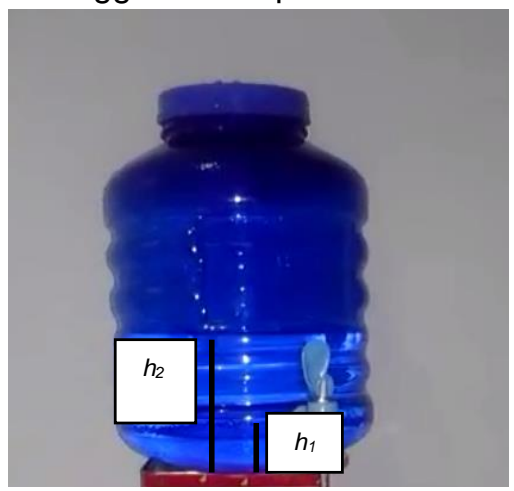

Gambar 3. Ketinggian air dalam galon

Hukum Torricelli yang digunakan tercantum pada persamaan 5. Karena gradien 
sebagaimana pada persamaan (3). $h_{2}$ adalah ketinggian seluruh volume air sedangkan $h_{1}$ adalah ketinggian air di bawah lubang. Jadi untuk mencari ketinggian pada kecepatan menggunakan selisih ketinggian volume cairan tersebut.

$$
\Delta h=h_{2}-h_{1}
$$

Galon disini dianggap sebagai sebuah tabung, jadi volumenya yaitu menggunakan volume tabung pada persamaan (4). Untuk mencari laju perubahan volume pada tabung menggunakan persamaan turunan pada persamaan (5). $\frac{d h}{d t}$ adalah $v$ (laju perubahan penurunan air) dicari menggunakan hukum Torricelli. Sehingga diperoleh data-data seperti pada bagian hasil. Setelah data diolah kemudian dianalisis maka diperoleh bahwa laju perubahan volume pada galon tersebut bergantung pada kecepatan aliran cairan, ketinggian volume cairan, dan jari-jari galon.

Hubungan antara laju perubahan volume dengan kecepatan aliran cairan berbanding lurus karena jika kecepatan airnya besar maka laju perubahan volumenya juga besar, sebaliknya jika kecepatan airnya kecil maka laju perubahan volumenya kecil.

\section{PENUTUP}

Berdasarkan penelitian ini didapatkan bahwa laju perubahan volume derbanding lurus dengan laju penurunan cairan. Waktu yang dibutuhkan untuk mengosongkan galon lebih cepat jika laju perubahan volumenya besar, sebaliknya jika laju perubahan volumenya kecil maka waktu yang dibutuhkannya lebih lama. Dengan hasil penelitian menunjukkan bahwa kecepatan cairan yang maksimum yaitu 0,22 $\mathrm{m} / \mathrm{s}$ dengan laju perubahan volume sebesar $0,010 \mathrm{~m}^{3} / \mathrm{s}$, dan kecepatan cairan minimumnya yaitu $0,063 \mathrm{~m} / \mathrm{s}$ dengan laju perubahan volume sebesar $0,0028 \mathrm{~m}^{3} / \mathrm{s}$.

\section{UCAPAN TERIMAKASIH}

Ucapan terimakasih kami tujukan kepada pihak-pihak yang telah membantu dalam penelitian ini khususnya kepada prodi pendidikan fisika Universitas Islam Negeri
(UIN) Sunan Gunung Djati Bandung.

\section{DAFTAR PUSTAKA}

Alfionita, F., \& Zulakmal. (2012). Penyelesaian Persamaan Diferensial Tunda Linier Orde 1 dengan Metode Karakteristik. Jurnal Matematika UNAND, 5 (2), 4549.

Alwi, W., Abidin, W., \& Ratnasari. (2015). Fungsi Green yang Dikonstruksi pada Persamaan Diferensial Linear Tak Homogen Orde-N. Jurnal MSA , 3 (1), 21-28.

Arwan, Azizah, T., \& Irwan. (2014). Menyelesaikan Turunan Tingkat Tinggi dengan Menggunakan Metode Selisih Orde Pusat Berbantuan Program Matlab. Jurnal MSA , $3(1), 66-70$.

Benenson, W. (2000). Handbook Of Physcis. Springer.

Djohan, W., \& Budhi, W. (2007). Diktat Klakulus 1. Bandung: ITB.

Fathonah, F., Zulkarnaen, D., \& Sukaesih, E. (2017). Pencarian Solusi Persamaan Diferensial Parsial Non Liner Menggunakan Metode Transformasi Pertubasi Homotopi dan Metode Dekomposisi Adomian. Jurnal Kubik , 2 (1), 35-42.

Groetsch, C. (2012). Inverse Problems and Torricelli's Law. The College Mathematics Journal , 39, 43-48.

Halliday, D., Resnick, R., \& Walker, J. (2005). Dasar-Dasar Fisika Jilid Satu. Jakarta: Binarupa Aksara Publisher.

Khamidiyah, K., \& Pagalay, U. (2014). Diskritisasi pada Sistem Persamaan Diferensial Parsial Pola Pembentukan Sel. CAUCHY, 3 (3), 131-137.

Mardiana, S., Susiswo, \& Hidayanto, E. (2016). Pemahaman Instrumental dan Relasional Mahasiswa dalam Menyelesaikan Masalah Turunan. Prosiding Seminar Matematika dan 
Pendidikan Matematika (hal. 67-76). Malang: Fkip.uns.ac.id.

Miranti, T., Hidayat, R., \& Kusbudiono. (2014). Solusi Persamaan Laplace Menggunakan Metode CrankNicholson. Prosiding Seminar Nasional Matematika (hal. 320-328). Jember: Universitas Jember.

Muhammad, S., Apriliani, E., \& Hanafi, L. (2015). Pengkajian Metode Extended Runge Kutta dan Penerapannya pada Persamaan Diferensial Biasa. Jurnal Sains dan Seni ITS , 4 (2), 25-30.

Nuraeni, Z. (2017). Aplikasi Persamaan Diferensial dalam Estimasi Jumlah Populasi. Delta Jurnal IImiah Pendidikan Matematika , 5 (1), 9-16.

Pratiwi, A., Widjajanti, T., \& Wyrasti, A. (2013). Penurunan Persamaan Saint Venant Secara Geometris. Beta , 6 (2), 172200.

Purcell, E., Varberg, D., \& Rigdon, S. (2007). Kalkulus Edisi Kesembilan Jilid I. Jakarta: Erlangga.

Ramdhani, S. (2017). Analisis Kemampuan Penalaran Analogis Mahasiswa Pendidikan Matematika dalam Persamaan Diferensial Orde Satu. Jurnal PRISMA Universitas Suryakancana , 6 (2), 162-172.

Salusu, A. (2012). Penyelesaian Persamaan Linear-No Linear dan Persamaan Differensial dengan Metode Kesamaan. Jurnal Mat Stat, 11 (2), 8291.

Side, S., Hirdi, S., \& Ja'farudin. (2015). Penyelesaian Persamaan LotkaVolterra dengan Metode Transformasi Diferensial. Jurnal MSA , 3 (1), 1-10.

Suciati, \& Sidarto, K. (2009). Suatu Contoh Inverse Problems yang Berkaitan dengan Hukum Torricelli. Prosiding Seminar Nasional Penelitian, Pendidikan dan Penerapan MIPA (hal. 237-242). Yogyakarta: Fakultas MIPA,
Universitas Negeri Yogyakarta.

Syafari, \& Sinaga, T. (2017). Perilaku Solusi Persamaan Diferensial Logistik dengan Pemberian Delay. Jurnal Scientific Pinisi , 3 (1), 39-47.

Tipler, P. A. (1998). Fisika untuk Sains dan Teknik. Jakarta: Erlangga.

Widyaningrum, I., Waluya, S., \& Wuryanto. (2012). Metode Multipler Time Scale untuk Penyelesaian Diferensial Tak Linear Sistem Double Shockbreaker. UNNES Journal of Mathematics , 1 (2), 79-85.

Yulida, Y. (2012). Metode Dekomposisi Adomian Laplace untuk Solusi Persamaan Diferensial Nonlinier Koefisien Fungsi. Jurnal Matematika Murni dan Terapan , 6 (1), 17-26. 